\title{
Influence of the battery model in the optimisation of stand-alone renewable systems
}

\author{
I.R. Cristóbal-Monreal ${ }^{1}$, R. Dufo-López ${ }^{2}$ and J. M. Yusta-Loyo² \\ ${ }^{1}$ Centro Universitario de la Defensa \\ Academia General Militar. Ctra. de Huesca s/n. 50.090 Zaragoza (Spain) \\ Phone/Fax number:+0034 9767398 37, e-mail: icristob@unizar.es \\ 2 Electrical Engineering Department, University of Zaragoza \\ C/ María de Luna, 3. 50018 Zaragoza \\ Phone/Fax number: +0034 9767619 21, e-mail: rdufo@unizar.es, jmyusta@unizar.es
}

\begin{abstract}
Stand-alone (off-grid) renewable systems are usually composed by photovoltaic panels and/or wind turbines, with batteries (usually lead-acid) and in some cases including diesel generator. In many cases the total cost of the batteries (including replacement during the lifetime of the system) is the highest cost.
\end{abstract}

The model of batteries used in simulation and optimisation of stand-alone renewable systems has a great importance as it allows the estimation of the lifetime of the batteries, which is one of the most important variables to calculate the Net Present Cost of the system and also the Levelised Cost of Energy.

The lifetime estimation of lead-acid batteries is a complex task because it depends on the operating conditions of the batteries. In many engineering works and research studies, the estimation of battery lifetime is error-prone, obtaining values much higher than the real ones.

In this paper we compare different models of lead-acid batteries, used in the simulation and optimisation of different stand-alone systems. We conclude that in many cases we obtain good results by using a complex weighted Ah-throughput model for the batteries, however using the classical models the estimation of the batteries lifetime is too optimistic.

\section{Key words}

Renewable stand-alone systems, batteries models, optimisation.

\section{Introduction}

In stand-alone renewable systems, the component with highest cost is the battery bank, considering acquisition cost, operation and maintenance (O\&M) cost and replacements of the component when it reaches its lifetime, during system lifetime. The correct estimation of the battery lifetime is very important as it determines the number of replacements of the battery bank during the lifetime of the system (which is usually considered as 20 or 25 years, same as the photovoltaic panels lifetime). For example, if the estimation of the lifetime of the batteries is 5 years and the system lifetime is 25 years, the battery bank will be expected to be replaced 5 times. However, if the real lifetime is 2.5 years, it will be replaced 10 times, and the real total Net Present Cost (NPC) of the system and the Levelised Cost of Energy (LCE) would be much higher than the expected ones.

Classical models like "Equivalent full cycles to failure" and "Rainflow cycle counting", widely used to estimate the lifetime of the batteries in simulation and optimisation tools [1] only consider the amount of energy cycled by the batteries, they do not take into account the operating conditions.

The most important ageing processes are anodic corrosion, positive active mass degradation and loss of adherence to the grid, irreversible formation of lead sulphate in the active mass, short-circuit, loss of water and electrolyte stratification [2].

Real batteries lifetime highly depends on the operating conditions, considering the capacity loss by degradation of the active mass (with the influence of the State Of Charge (SOC), the time that the batteries are in a low state of charge, the time since the last full charge, the current, acid stratification...) and the capacity loss by corrosion (with the influence of the cell voltage, temperature and other factors) [3].

Batteries subject to deep cycling regimes typically age by degradation of the structure of the positive active mass. The battery cycle lifetime shown in the datasheet of the batteries (several hundreds of full cycles) is obtained in laboratory tests under standard conditions. However, the real conditions can be very different from standard conditions. Then the ageing by degradation of the active mass and therefore the lifetime can be very different from the expected. 
In the case of stationary batteries (operating under floatcharge conditions), the most important ageing mechanism is corrosion of the positive grid. The real conditions of stationary batteries can be different from the laboratory tests, so the real floating life can be very different (usually lower) than floating life shown in the datasheet (which is at 20 or $25^{\circ} \mathrm{C}$ ), as the effect of temperature on float life is around $50 \%$ reduction for each $8.3{ }^{\circ} \mathrm{C}$ increase in temperature for lead-acid batteries.

Classical models used to estimate the lifetime of the batteries are very simple but they can imply high errors. Much more complex models like weighted Ah-throughput approach can bring much more accurate results [3].

\section{Battery ageing models}

In this paper we compare three models of batteries:

1) Equivalent full cycles to failure

2) Rainflow cycle counting

3) Weighted Ah-throughput model proposed by Schiffer et al. in 2007 [4]

\section{A. Equivalent full cycles to failure}

This method is widely used by many simulation and optimisation tools [1]. The end of the battery lifetime is expected to be reached when a specified number of full charge-discharge cycles are reached, shown in the manufacturer's datasheet. This model only consider the amount of energy cycled by the batteries, it does not take into account the operating conditions.

\section{B. Rainflow cycle counting}

This model is known as “rainflow”, based on Downing's algorithm [5] that is used by HYBRID2 software [6]. It is more complex than equivalent full cycles to failure. This model counts the charge/discharge cycles $Z_{i}$ corresponding to each range of the Depth of Discharge (DOD), split in $m$ intervals of $D O D_{i}$, for a year. For each interval there is a number of Cycles to Failure $\left(C F_{i}\right)$ obtained from the manufacturer's datasheet (example shown in Fig. 1).

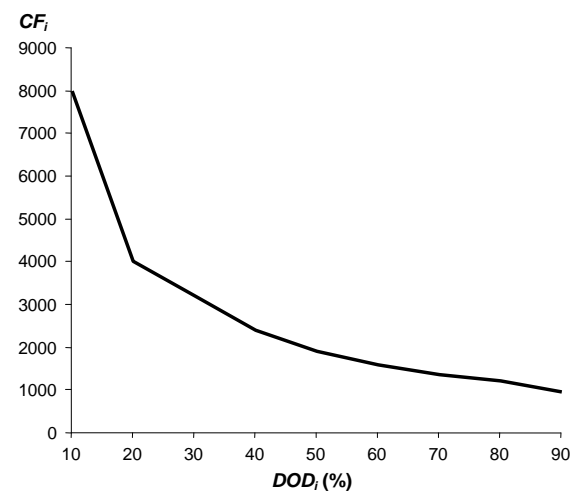

Fig. 1. Cycles to Failure vs. Depth of Discharge.

The battery expected lifetime, in years, can be calculated as follows:

$$
\text { Life }_{b a t}=\frac{1}{\sum_{i=1}^{m} \frac{Z_{i}}{C F_{i}}}
$$

This model considers the depth of discharge of the cycles, but it does not consider the rest of the operating conditions (time that batteries are in a low SOC, time since the last full charge, current, acid stratification, voltage, temperature...).

\section{Schiffer weighted Ah-throughput model}

This is a weighted Ah-throughput model proposed by Schiffer et al. [4]. It considers real operating conditions.

The actual Ah throughput is continuously multiplied by a weight factor that represents the actual operating conditions.

This model calculates the capacity loss by corrosion and the capacity loss by degradation. The remaining battery capacity is the normalised initial battery capacity minus the capacity loss by corrosion and degradation. The end of the battery lifetime is reached when its remaining capacity is $80 \%$ of the nominal capacity.

It takes into account the influence of the SOC, the time that the batteries are in a low state of charge, the time since the last full charge, the current, the acid stratification, the cell voltage, the temperature and other factors. By using this model, the effect of the voltage cut limits of the battery controller can be modelled, and also other parameters which can be set in the battery controller [3].

It is a complex model which uses many equations, detailed information can be seen in [4] and [3]. In [3] we demonstrated that this model is much more accurate and predicts batteries lifetime much better than the other models. Classical models (the equivalent full cycles model or the rainflow cycle counting model) do not correctly estimate the ageing of the batteries; in many cases, the predicted battery lifetime is two or three times higher than the lifetime obtained in the real system; however, using the Schiffer weighted Ah model, predictions are very similar to real lifetimes [3].

The Schiffer weighted Ah model has been added in iHOGA software [7], which is the only software for the simulation and optimisation of hybrid renewable systems which incorporates such an accurate model.

\section{Stand-alone renewable system}

Fig. 2 shows the system to be simulated and optimized. It will supply an AC load, and can be composed by photovoltaic (PV) array, a battery bank, a Diesel generator and a inverter/charger controller. 


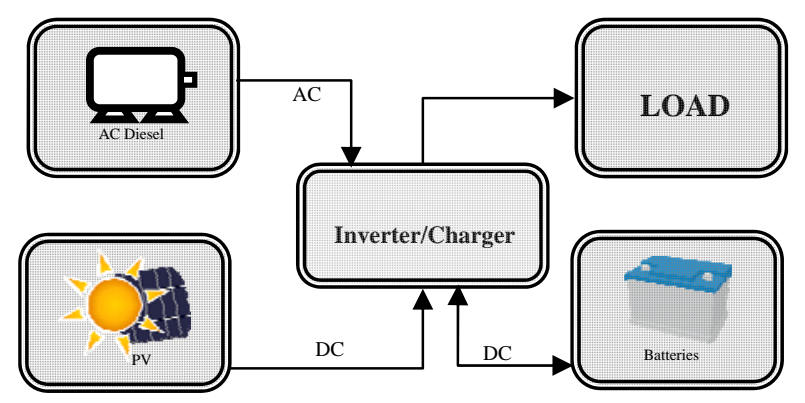

Fig. 2. PV-Diesel-battery system

We will consider three different configurations:

1) PV-batteries system

2) PV-Diesel-batteries system

3) Diesel-batteries system (non-renewable system)

The three configurations will be optimized in order to supply the load with the lowest cost. For the three cases of systems, we will use the three cases of battery ageing models, seeing the differences in the results.

A system located near Sabiñánigo $\left(42.53^{\circ} \mathrm{N}, 0.37^{\circ} \mathrm{W}\right.$, close to Pyrenees mountains, in Aragon, Spain) has been evaluated. Two load profiles has been considered:

1) AC Household load (3.63 kWh/day, following a typical hourly distribution shown in Fig. 3)

2) DC Telecom station load (2.88 kWh/day, continuous load of $120 \mathrm{~W}$ )

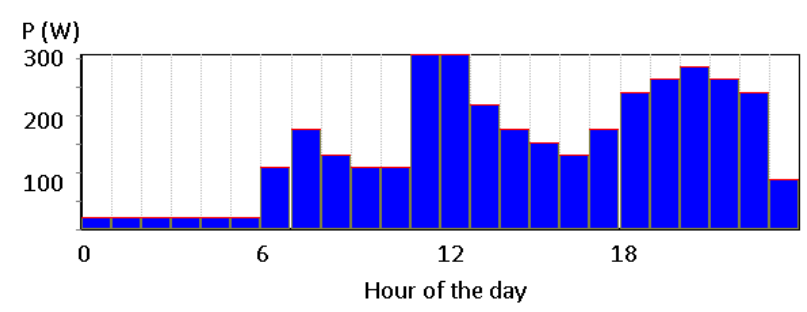

Fig. 3. Hourly distribution of AC household load

The irradiation for the location has been obtained by means of the web of PVGIS, JRC European Commission [8].

The PV panels used in the optimisation are of $100 \mathrm{Wp}$ peak power, $17.7 \mathrm{~V}$ open voltage, 6.79 A shortcut current, $143 €$ acquisition cost (including support), O\&M cost 1.43 $€ /$ year (1\% of acquisition cost), expected lifetime 25 years. The selected slope for the PV panels is the optimal one $\left(65^{\circ}\right)$, with azimuth $0^{\circ}$.

The batteries used in the optimisation are a OPzS lead-acid batteries family, with 1,258 full cycles to failure and cycles to failure vs. DOD shown in Fig. 4 (red curve). Also in same figure the cycled energy during lifetime is shown in green. Floating life is 18 years. The capacity of the batteries of the family is from 180 to 3360 Ah. The nominal voltage is $2 \mathrm{~V}$. The acquisition cost is around 190 $€ / \mathrm{kWh}$, and the O\&M annual cost is $1 \%$ of the acquisition cost.

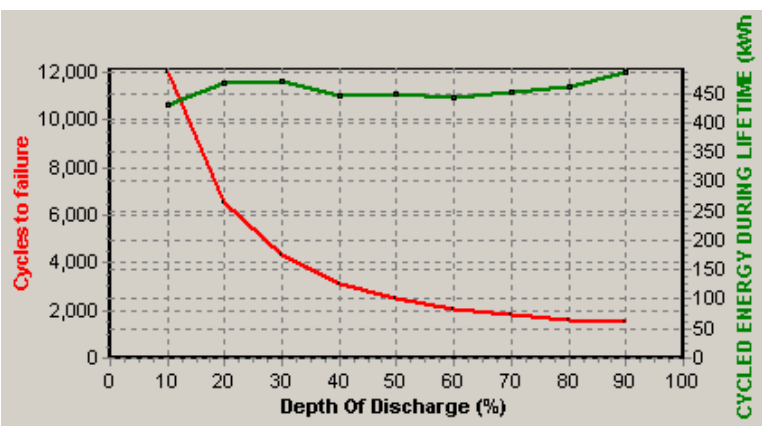

Fig. 4. Cycles to Failure vs. Depth of Discharge of the batteries used in the optimisations.

Three generators have been considered:

A diesel of $1.9 \mathrm{kVA}, 1040 €$ of acquisition cost, and two gasoline generators, one of $0.5 \mathrm{kVA}$ and another of 1 $\mathrm{kVA}$ (325 and $520 €$ of acquisition cost, respectively). Their O\&M cost is $0.15 € / h$ for the Diesel and $0.23 € / h$ for the gasoline generators.

Also several inverter/chargers have been considered for the different cases.

For all the cases a DC bus voltage of $48 \mathrm{~V}$ has been considered. Also, for all the cases when there is a diesel (or gasoline) generator, the strategy "Cycle charging" is used [9]: whenever the load cannot be supplied by the PV nor the batteries, the diesel (or gasoline) runs at full power, charging batteries until $100 \%$ of SOC is reached. Also for all the cases interest annual rate of $2 \%$ and annual inflation of $4 \%$ have been taken into account to calculate NPC and LCE.

\section{Computational results}

The optimisation of each system to supply the load has been done three times, one for each battery ageing model.

\section{A. Household load}

Tables I, II and III show the optimal system found for the different configurations (PV-batteries, PV-Dieselbatteries and Diesel-batteries, respectively) using for each configuration the three battery ageing models.

Table I. - Results for Household load, PV-batteries.

\begin{tabular}{|c|c|c|c|c|}
\hline $\begin{array}{c}\text { Battery } \\
\text { ageing } \\
\text { model }\end{array}$ & Optimal system & $\begin{array}{c}\text { Battery } \\
\text { expected } \\
\text { lifetime } \\
\text { (years) }\end{array}$ & $\begin{array}{c}\text { NPC } \\
(€)\end{array}$ & $\begin{array}{c}\text { LCE } \\
(€ / \mathrm{kWh})\end{array}$ \\
\hline $\begin{array}{c}\text { Equivalent } \\
\text { full cycles to } \\
\text { failure }\end{array}$ & $\begin{array}{c}\text { PV } 2000 \mathrm{Wp} \\
\text { Batt. } 18.72 \mathrm{kWh}\end{array}$ & 18 & 21074 & 0.64 \\
\hline $\begin{array}{c}\text { Rainflow } \\
\text { cycle } \\
\text { counting }\end{array}$ & $\begin{array}{c}\text { PV } 2000 \mathrm{Wp} \\
\text { Batt. } 18.72 \mathrm{kWh}\end{array}$ & 18 & 21074 & 0.64 \\
\hline $\begin{array}{c}\text { Schiffer } \\
\text { Weighted } \\
\text { Ah- } \\
\text { throughput }\end{array}$ & $\begin{array}{c}\text { PV } 2000 \mathrm{Wp} \\
\text { Batt. } 18.72 \mathrm{kWh}\end{array}$ & 8.12 & 25366 & 0.77 \\
\hline
\end{tabular}


Table II. - Results for Household load, PV-Diesel-batteries.

\begin{tabular}{|c|c|c|c|c|}
\hline $\begin{array}{c}\text { Battery } \\
\text { ageing } \\
\text { model }\end{array}$ & Optimal system & $\begin{array}{c}\text { Battery } \\
\text { expected } \\
\text { lifetime } \\
\text { (years) }\end{array}$ & $\begin{array}{c}\text { NPC } \\
(€)\end{array}$ & $\begin{array}{c}\text { LCE } \\
(€ / \mathrm{kWh})\end{array}$ \\
\hline $\begin{array}{c}\text { Equivalent } \\
\text { full cycles } \\
\text { to failure }\end{array}$ & $\begin{array}{c}\text { PV } 1600 \mathrm{Wp} \\
\text { Diesel } 1.9 \mathrm{kVA} \\
\text { Batt. 8.64 kWh }\end{array}$ & 13.61 & 19322 & 0.58 \\
\hline $\begin{array}{c}\text { Rainflow } \\
\text { cycle } \\
\text { counting }\end{array}$ & $\begin{array}{c}\text { PV } 1600 \mathrm{Wp} \\
\text { Diesel } 1.9 \mathrm{kVA} \\
\text { Batt. 8.64 kWh }\end{array}$ & 15.8 & 18857 & 0.57 \\
\hline $\begin{array}{c}\text { Schiffer } \\
\text { Weighted } \\
\text { Ah- }\end{array}$ & $\begin{array}{c}\text { PV } 1600 \mathrm{Wp} \\
\text { Diesel } 1.9 \mathrm{kVA} \\
\text { Batt. 8.64 kWh }\end{array}$ & 8.92 & 21783 & 0.66 \\
\hline
\end{tabular}

Table III. - Results for Household load, Diesel-batteries.

\begin{tabular}{|c|c|c|c|c|}
\hline $\begin{array}{c}\text { Battery } \\
\text { ageing } \\
\text { model }\end{array}$ & Optimal system & $\begin{array}{c}\text { Battery } \\
\text { expected } \\
\text { lifetime } \\
\text { (years) }\end{array}$ & $\begin{array}{c}\text { NPC } \\
(€)\end{array}$ & $\begin{array}{c}\text { LCE } \\
(€ / \mathrm{kWh})\end{array}$ \\
\hline $\begin{array}{c}\text { Equivalent } \\
\text { full cycles } \\
\text { to failure }\end{array}$ & $\begin{array}{c}\text { Diesel } 1.9 \mathrm{kVA} \\
\text { Batt. } 18.72 \mathrm{kWh}\end{array}$ & 16.76 & 47244 & 1.43 \\
\hline $\begin{array}{c}\text { Rainflow } \\
\text { cycle } \\
\text { counting }\end{array}$ & $\begin{array}{c}\text { Diesel } 1.9 \mathrm{kVA} \\
\text { Batt. } 18.72 \mathrm{kWh}\end{array}$ & 18 & 46902 & 1.42 \\
\hline $\begin{array}{c}\text { Schiffer } \\
\text { Weighted } \\
\text { Ah- } \\
\text { throughput }\end{array}$ & $\begin{array}{c}\text { Diesel } 1.9 \mathrm{kVA} \\
\text { Batt. } 8.64 \mathrm{kWh}\end{array}$ & 4.8 & 55334 & 1.67 \\
\hline
\end{tabular}

\section{B. Telecom station}

Tables IV, V and VI show the optimal system found for the different configurations (PV-batteries, PV-Dieselbatteries and Diesel-batteries, respectively) using for each configuration the three battery ageing models.

Table IV. - Results for Telecom load, PV-batteries.

\begin{tabular}{|c|c|c|c|c|}
\hline $\begin{array}{c}\text { Battery } \\
\text { ageing } \\
\text { model }\end{array}$ & Optimal system & $\begin{array}{c}\text { Battery } \\
\text { expected } \\
\text { lifetime } \\
\text { (years) }\end{array}$ & $\begin{array}{c}\text { NPC } \\
(€)\end{array}$ & $\begin{array}{c}\text { LCE } \\
(€ / \mathrm{kWh})\end{array}$ \\
\hline $\begin{array}{c}\text { Equivalent } \\
\text { full cycles to } \\
\text { failure }\end{array}$ & $\begin{array}{c}\text { PV } 1200 \mathrm{Wp} \\
\text { Batt. } 18.72 \mathrm{kWh}\end{array}$ & 18 & 13904 & 0.53 \\
\hline $\begin{array}{c}\text { Rainflow } \\
\text { cycle } \\
\text { counting }\end{array}$ & $\begin{array}{c}\text { PV } 1200 \mathrm{Wp} \\
\text { Batt. } 18.72 \mathrm{kWh}\end{array}$ & 18 & 13904 & 0.53 \\
\hline $\begin{array}{c}\text { Schiffer } \\
\text { Weighted } \\
\text { Ah- } \\
\text { throughput }\end{array}$ & $\begin{array}{c}\text { PV } 1200 \mathrm{Wp} \\
\text { Batt. } 18.72 \mathrm{kWh}\end{array}$ & 7.68 & 18797 & 0.72 \\
\hline
\end{tabular}

Table V. - Results for Telecom load, PV-Diesel-batteries.

\begin{tabular}{|c|c|c|c|c|}
\hline $\begin{array}{c}\text { Battery } \\
\text { ageing } \\
\text { model }\end{array}$ & Optimal system & $\begin{array}{c}\text { Battery } \\
\text { expected } \\
\text { lifetime } \\
\text { (years) }\end{array}$ & $\begin{array}{c}\text { NPC } \\
(€)\end{array}$ & $\begin{array}{c}\text { LCE } \\
(€ / \mathrm{kWh})\end{array}$ \\
\hline $\begin{array}{c}\text { Equivalent } \\
\text { full cycles } \\
\text { to failure }\end{array}$ & $\begin{array}{c}\text { PV } 1600 \mathrm{Wp} \\
\text { Gasoline } 0.5 \mathrm{kVA} \\
\text { Batt. } 8.64 \mathrm{kWh}\end{array}$ & 17.64 & 13931 & 0.53 \\
\hline $\begin{array}{c}\text { Rainflow } \\
\text { cycle } \\
\text { counting }\end{array}$ & $\begin{array}{c}\text { PV } 1600 \mathrm{Wp} \\
\text { Gasoline } 0.5 \mathrm{kVA} \\
\text { Batt. } 8.64 \mathrm{kWh}\end{array}$ & 17.68 & 13927 & 0.53 \\
\hline $\begin{array}{c}\text { Schiffer } \\
\text { Weighted } \\
\text { Ah- } \\
\text { throughput }\end{array}$ & $\begin{array}{c}\text { PV } 1600 \mathrm{Wp} \\
\text { Gasoline } 0.5 \mathrm{kVA} \\
\text { Batt. } 8.64 \mathrm{kWh}\end{array}$ & 8.61 & 16828 & 0.64 \\
\hline
\end{tabular}

Table VI. - Results for Telecom load, Diesel-batteries.

\begin{tabular}{|c|c|c|c|c|}
\hline $\begin{array}{c}\text { Battery } \\
\text { ageing } \\
\text { model }\end{array}$ & Optimal system & $\begin{array}{c}\text { Battery } \\
\text { expected } \\
\text { lifetime } \\
\text { (years) }\end{array}$ & $\begin{array}{c}\text { NPC } \\
(€)\end{array}$ & $\begin{array}{c}\text { LCE } \\
(€ / \mathrm{kWh})\end{array}$ \\
\hline $\begin{array}{c}\text { Equivalent } \\
\text { full cycles } \\
\text { to failure }\end{array}$ & $\begin{array}{c}\text { Diesel } 1.9 \mathrm{kVA} \\
\text { Batt. } 18.72 \mathrm{kWh}\end{array}$ & 18 & 34911 & 1.33 \\
\hline $\begin{array}{c}\text { Rainflow } \\
\text { cycle } \\
\text { counting }\end{array}$ & $\begin{array}{c}\text { Diesel } 1.9 \mathrm{kVA} \\
\text { Batt. } 18.72 \mathrm{kWh}\end{array}$ & 18 & 34911 & 1.33 \\
\hline $\begin{array}{c}\text { Schiffer } \\
\text { Weighted } \\
\text { Ah- } \\
\text { throughput }\end{array}$ & $\begin{array}{c}\text { Diesel } 1.9 \mathrm{kVA} \\
\text { Batt. } 8.64 \mathrm{kWh}\end{array}$ & 5.23 & 42711 & 1.63 \\
\hline
\end{tabular}

The results show that the three ageing models obtain same optimal system in PV-Diesel-batteries and in PVbatteries systems. However, in the case of Dieselbatteries system the Schiffer weighted Ah-throughput model obtains a optimal system with lower battery bank.

The classical models ("Equivalent full cycles to failure" and "Rainflow cycle counting") obtain very similar estimation for the battery lifetime and then very similar NPC and LCE. However, Schiffer weighted Ahthroughput model obtains more realistic results for the batteries expected lifetime (much lower than the values obtained with the classical models), then expected NPC and LCE are more realistic (higher than the values obtained with the other models).

\section{Conclusion}

In this paper we compare three different batteries ageing models to be used in the simulation and optimisation of hybrid renewable systems. Two models are simple and classical ones: "Equivalent full cycles to failure" and "Rainflow cycle counting", and the third model is a complex weighted Ah-throughput model proposed by Schiffer et al. in 2007 [4]. 
We optimize three types of systems: PV-batteries, PVDiesel-batteries and Diesel-batteries. We use two different loads, a household AC load and a telecom station continuous DC load.

Comparing the results for the different optimisations, we conclude in the cases studied all the models obtain same optimal system (except for the case of Diesel-batteries, where Schiffer model obtains a lower battery bank in the optimal system).

However, in NPC and LCE the results are very different comparing the classical models to the Schiffer model. The Schiffer Ah-throughput model obtains more realistic results (lower battery lifetime and therefore higher NPC and LCE). Classical models obtain too optimistic results for the battery lifetime, in some cases two or three times higher than values obtained with Schiffer model.

\section{References}

[1] Bernal-Agustín JL, Dufo-López R. Simulation and optimization of stand-alone hybrid renewable energy systems. Renew Sustain Energy Rev 2009;13:2111-8.

[2] Ruetschi P. Aging mechanisms and service life of lead-acid batteries. J Power Sources 2004;127:33-44

[3] Dufo-López R, Lujano-Rojas JM, Bernal-Agustín JL. Comparison of different lead-acid battery lifetime prediction models for use in simulation of stand-alone photovoltaic systems. Appl Energy 2014;115:242-53. doi:10.1016/j.apenergy.2013.11.021.

[4] Schiffer J, Sauer DU, Bindner H, Cronin T, Lundsager P, Kaiser R. Model prediction for ranking lead-acid batteries according to expected lifetime in renewable energy systems and autonomous power-supply systems. J Power Sources 2007;168:66-78.

[5] Downing SD, Socie DF. Simple rainflow counting algorithms. Int J Fatigue 1982;4:31-40.

[6] Green HJ, Manwell J. HYBRID2 - A Versatile Model of the Performance of Hybrid Power Systems. Proceedings of WindPower'95, Washington DC, March 27-30, 1995.

[7] iHOGA software. Rodolfo Dufo-López. Free educational versión can be downloaded from: http://personal.unizar.es/rdufo/index.php?lang=en

[8] PVGIS, interactive maps. JCR European Commission: http://re.jrc.ec.europa.eu/pvgis/apps4/pvest.php\#

[9] Dufo-López R, Bernal-Agustín JL. Design and control strategies of PV-Diesel systems using genetic algorithms. Sol Energy 2005;79:33-46. doi:10.1016/j.solener.2004.10.004. 